\title{
Testing of Growth Promoting and Protective Activity of the Probiotic Lactiferm in Weaned Piglets
}

\author{
I. HERZIG, E. GÖPFERT, B. PÍSAŘIIKOVÁ, E. STRAKOVÁ ${ }^{1}$ \\ Veterinary Research Institute, Brno \\ ${ }^{1}$ University of Veterinary and Pharmaceutical Sciences, Brno
}

Received January 17, 2003

Accepted September 22, 2003

\begin{abstract}
Herzig I., E. Göpfert, B. Písaříková, E. Straková: Testing of Growth Promoting and Protective Activity of the Probiotic Lactiferm in Weaned Piglets. Acta Vet. Brno 2003, 72: 331338.

A positive effect of the probiotic product Lactiferm containing Enterococcus faecium M 74 (NCIMB 11181) as an active component on the performance of weaned piglets was found. Animals of the experimental group had non-significantly higher weight from 4.1 to $11.1 \%$ during the entire experiment. However, weight gains in the period between days 15 and 38 of the experiment and total weight gains were significantly higher $(P<0.05)$ compared with controls. Feed conversion was 1.905 and $1.872 \mathrm{~kg}$ in the control and experimental groups, respectively. The levels of selected biochemical and haematological characteristics ranged within physiological or reference values. No clinical signs of disease were observed in piglets.
\end{abstract}

Enterococcus faecium M 74, performance, metabolic profile, haematological profile

Biological preparations with preventive action against various intestinal infections and positive effect on digestibility and utilization of nutrients are common components of the complete feed mixtures for farm animal nutrition. At present, there is a tendency to exclude antibiotics and chemical stimulators from the nutrition of farm animals, therefore biological preparations with stabilized microbial cultures on a carrier as an active substance are administered to animals either as a dietary supplementation or orally in certain time intervals.

Preparations of this type are included to the group of additives, are called "probiotics" and several species of microorganisms are used for their production, especially lactobacilli, streptococci, bifidobacteria, bacilli and yeasts. Specific benefits of these additives consist in: - stimulation of the immune system and protective effect by increased formation of antibodies and increased effectiveness of macrophages against pathogenic bacteria;

- support of adhesion of lactobacilli to intestinal epithelium;

- ability to excrete salmonellae from intestinal tract;

- growth inhibition of potential pathogenic microorganisms by decreasing $\mathrm{pH}$ through production of lactate, lactic acid and free fatty acids;

- enhanced performance (increased weight gains and better feed conversion), and digestion of anti-nutritional substances.

The mechanisms of action of probiotics were studied by Gedek (1990), Fuller (1992, 1989), Goldin and Gorbach (1984), Kumprecht et al. (1990), Herich and Levkut (2002) and others. Several authors, e.g. Nguyen (1989), Nguyen et al. (1988), Michard and Levesque (1989), Kumprecht et al. (1994), Kumprecht and Zobač (1998a, b) published the results of in vitro and in vivo experiments in which positive effects of probiotics on various animal species were obtained. Ghadban (2002) reviewed this problem.

Address for correspondence: Doc. MVDr. Ivan Herzig, CSc. Veterinary Research Institute Czech Republic
Phone: +42054132124

E-mail: herzig@vricz 
Regarding the fact that in substances of this type a certain drop in efficiency cannot be excluded, the objective of our study was to test growth promoting activity and protective effect of the probiotic preparation Lactiferm on piglets. Enterococcus faecium M74 (NCIMB 11181), that is the active component of this preparation, ranks among microbial supplements approved by the Notice No. 451/2000 issued by the Ministry of Agriculture of the Czech Republic.

\section{Materials and Methods}

As recommended by the Scientific Committee on Animal Nutrition (SCAN), the efficacy of microbial feed supplements shall be assessed according to the Directive No. 87/153/EEC. The experiments shall be arranged and conducted in due form using animal group sizes that are satisfactory for establishing the minimum claimed response. The recommended testing period for piglets is from weaning to live weight of $25 \mathrm{~kg}$. Variation coefficient 10 is recommended for statistical testing of live weight uniformity in piglets (Notice No. 451/2000, Annex 20, issued by the Ministry of Agriculture of the Czech Republic).

The experiment was conducted under good hygienic conditions in two identical, separated rooms of an experimental barn of the Veterinary Research Institute in Brno. The piglets were kept in groups of ten in strawbedded pens $3.8 \times 4.5 \mathrm{~m}\left(17 \mathrm{~m}^{2}\right)$. Air temperature and humidity were recorded twice a day throughout the testing period.

The experiment was conducted on 20 piglets (10 males and 10 females) of the same breed (Large white $x$ Landrace) and average live weight $6.7 \pm 0.785 \mathrm{~kg}$. The piglets were purchased from the Agricultural Cooperative Nikol. and were earmarked by tattooing.

The experiment was preceded by an 11-day period during which the piglets were adapted to the new environment and new diet and were monitored for performance, growth uniformity and health. In this pre-treatment period all animals were fed the same complete feed mixture without the active component of Lactiferm. Deworming was omitted with regard to the negative results of examination of faecal samples.

To assure maximum uniformity, the piglets were divided into two groups (control and experimental) of ten piglets each, by selection of pairs similar in terms of sex, live weight and growth rate during the pre-treatment period. Table 3 shows live weights and weight gains in the control $(n=10)$ and experimental groups $(n=10)$. The differences were non-significant. Variation coefficient $(10.7 \%)$ corresponded to that required or was slightly higher (13.2\%). The biological tests ran for 45 days.

Table 1

Percentage of the starter components

\begin{tabular}{lcc}
\hline & $\begin{array}{c}\text { Control diet } \\
\text { AO/C }\end{array}$ & $\begin{array}{c}\text { Experimental diet } \\
\text { AO/E }\end{array}$ \\
\hline Wheat & 45.5 & 45.5 \\
Barley & 30.0 & 30.0 \\
Extracted soy meal 46\% CP & 15.0 & 15.0 \\
Fish meal 62\% & 2.50 & 2.50 \\
Trast Vitex Q & 2.50 & 2.50 \\
Soy oil & 0.90 & 0.90 \\
Lysine-HCl 100\% & 0.41 & 0.41 \\
DL-methionine 100\% & 0.06 & 0.06 \\
L-threonine 100\% & 0.14 & 0.14 \\
Monocalcium phosphate MCP-F & 0.48 & 0.48 \\
Monosodium phosphate & 0.19 & 0.19 \\
Salt & 0.27 & 0.27 \\
Ground limestone & 1.55 & 1.52 \\
Lactiferm premix L5 & 0.00 & 0.03 \\
Phytase-free premix P-1 (vitamins \& minerals) & 0.50 & 0.50 \\
\hline Total & 100.0 & 100.0 \\
\hline
\end{tabular}


The diets $\mathrm{AO} / \mathrm{C}$ and $\mathrm{AO} / \mathrm{E}$ contained the following ingredients: grains, products and offal of oil-containing crops, fish products, yeasts, minerals, oils and fats, 3.2.3 L-lysine monohydrochloride, 3.3.1 L-threonine, 3.1.1, DL-methionine, copper sulphate pentahydrate $\left(\mathrm{CuSO}_{4} \cdot 5 \mathrm{H}_{2} \mathrm{O}\right)$, butylhydroxy toluene, ethoxyquin, and propylgalate. Percentages of the above components are shown in Table 1.

The two groups were fed the same starter diet for meat type pigs twice a day throughout the experimental period. The only difference between the diets for the control $(\mathrm{AO} / \mathrm{C})$ and the experimental $(\mathrm{AO} / \mathrm{E})$ groups was the presence of in the latter of the probiotic Lactiferm containing Enterococcus faecium M74 (NCIMB 11181) as the active component. Probiotic bacteria have a positive effect on the composition of gut microflora in the host and can eliminate multiplication of facultatively pathogenic and pathogenic microorganisms. Their growthstimulating properties are also important. The composition of feed mixture was based on the requirement of nutrients for each weight category of piglets. The amount of the offered feed was adjusted to the actual intake and live weight of the piglets to assure only small leftovers after each feeding. The diet was offered in troughs mixed with water $1: 1$. Feed consumption was monitored by weighing the leftovers. The piglets had unlimited access to drinking water.

The diet was analyzed for the contents of basic nutrients (Notice No. 194/1966, Annex 3, issued by the Ministry of Agriculture of the Czech Republic). Tests for CFU (colony forming units) in the control and experimental diets were carried out in the laboratories of Medipharm CZ, Ltd.

Basic characteristics of the strain Enterococcus faecium M74 (NCIMB 11181): Gram-positive coccus, facultatively anaerobic, nonhaemolytic, homofermentative production of lactic acid (L+ form), optimum growth temperature at $37^{\circ} \mathrm{C}$, growth range at 16 to $45^{\circ} \mathrm{C}, \mathrm{pH} 4.2$ to 9.6 ; mean generation time $18 \mathrm{~min}$ ( 16 to $20 \mathrm{~min}$ ). The strain is a natural inhabitant of the digestive tract of animals, in particular the young ones; acting as a favourable symbiotic component of the gut microbial population. The original strain was isolated from intestinal tract of a healthy suckling infant. Experimental diet AO/E contained probiotic product Lactiferm premix L5 (CFU $\left.5 \times 10^{9} \cdot \mathrm{g}^{-1}\right) 300 \mathrm{~g} \cdot \mathrm{l}^{-1} \mathrm{t}$ of feed.

The piglets were weighed in the agricultural cooperative before loading for the transport, then on the first day of the pre-treatment period, at the beginning of the experiment, twice during the experimental period and at the end of the experiment. The weighing precision was $0.1 \mathrm{~kg}$. Each weighing was done at the same time and at the same group order.

Blood samples for laboratory examinations were collected from v. cava cranialis at the beginning and at the end of the experiment. Blood sera were analyzed for total proteins, albumin, total lipids, cholesterol, glucose, alkaline phosphatase (ALP, EC 3.1.3.1), transferases (AST, EC 2.6.1.1; ALT, EC 2.6.1.2), calcium and phosphorus. The samples were analyzed in laboratories of the Veterinary Research Institute, Brno, using the Bio-La-Tests (Lachema, Brno). Haematological examinations (erythrocyte count, haematocrit, haemoglobin, leucocyte count) were carried out in the laboratories of the Department of Nutrition, Dietetics, Animal Hygiene, and Vegetable Feeds, University of Veterinary and Pharmaceutical Sciences, Brno, using conventional methods.

The state of health of piglets was checked daily by observation. Diarrhoea or other health disorders were recorded individually. Post-mortem examination was presumed for dying piglets if any. All events observed during the experiment including health disorders were recorded.

The results were processed by statistical methods including calculations of arithmetic means, standard deviations (SD), variation coefficients, ranges and significance of the testing $(P<0.05, P<0.01)$. The statistical and graphic software STAT Plus (Matoušková et al. 1992) was used.

\section{Results}

Regarding the fact that any change in the diet during the test period and the necessary adaptation associated therewith could significantly influence the results, the same starter diet was fed during the pre-treatment and treatment periods with the initial and the final live weights 7.0 and $25 \mathrm{~kg}$, respectively. The contents of nutrients (Table 2) in the diet was appropriate for the live weight category 11 to $25 \mathrm{~kg}$ (Šimeček et al. 1993) matching the treatment period. The requirement for nitrogenous substances ranges from 180 to $210 \mathrm{~g} \cdot \mathrm{kg}^{-1}$ and that for metabolisable energy from 12.9 to $13 \mathrm{MJ} \cdot \mathrm{kg}^{-1}$; the content of fibre should not be higher than 43 to $48 \mathrm{~g} \cdot \mathrm{kg}^{-1}$. Our experimental diet $(\mathrm{AO} / \mathrm{E})$ contained $1580 \times 10^{3} \mathrm{CFU}$ Enterococcus faecium M 74 (NCIMB 11181).

Mean live weight of the piglets $(n=20)$ was $6.70 \pm 0.79 \mathrm{~kg}$ at the beginning and $8.85 \pm 1.02$ $\mathrm{kg}$ at the end of the 11-day pre-treatment period. Mean weigh gain $1.39 \pm 0.48 \mathrm{~kg}$. The piglets were weighed on the first day and on the last day of the pre-treatment period. They were also weighed on days 1, 15, 38 and 46 of the experimental period. Mean initial live weights of the control and experimental groups were $8.09 \pm 1.08 \mathrm{~kg}$ (index 100) and $8.08 \pm 1.02 \mathrm{~kg}$ (index 99.9), respectively. Growth rate in the experimental group was higher during the 
Table 2

Nutrient contents in the diets $\left(\mathrm{g} \cdot \mathrm{kg}^{-1}\right)$

\begin{tabular}{|c|c|c|c|c|}
\hline \multirow[t]{2}{*}{ Component } & \multicolumn{2}{|c|}{ Control diet $\mathrm{AO} / \mathrm{C}$} & \multicolumn{2}{|c|}{ Experimental diet $\mathrm{AO} / \mathrm{E}$} \\
\hline & Sample & Dry matter & Sample & Dry matter \\
\hline Dry matter $\quad\left(\mathrm{g} \cdot \mathrm{kg}^{-1}\right)$ & 878.3 & 1000.0 & 878.7 & 1000.0 \\
\hline Nitrogenous substances & 180.4 & 205.4 & 184.6 & 210.1 \\
\hline Fat & 26.4 & 30.1 & 26.9 & 30.6 \\
\hline Fibre & 26.6 & 30.3 & 26.0 & 29.6 \\
\hline Ash & 53.5 & 60.9 & 53.8 & 61.2 \\
\hline Total & 286.9 & 326.7 & 291.3 & 331.5 \\
\hline N-FE & 591.4 & 673.3 & 587.4 & 668.5 \\
\hline $\mathrm{OM}$ & 824.8 & 939.1 & 824.9 & 938.8 \\
\hline TDN & 758.0 & 863.0 & 761.0 & 866.0 \\
\hline $\mathrm{MJ} \cdot \mathrm{kg}^{-1}$ & 13.3 & 15.1 & 13.4 & 15.2 \\
\hline
\end{tabular}

$\mathrm{N}-\mathrm{FE}$ - nitrogen-free extracts

$\mathrm{OM}$ - organic matter

TDN - total digestible nutrients

MEp - metabolisable energy

treatment period as indicated by later live weight changes: $12.0 \mathrm{~kg}$ vs. $11.53 \mathrm{~kg}$ (index 104.1 ), $27.56 \mathrm{~kg}$ vs. $24.81 \mathrm{~kg}$ (index 111.1 ), and $32.7 \mathrm{~kg}$ vs. $30.91 \mathrm{~kg}$ (index 105.8). Live weight of the experimental group was non-significantly higher than that of the control group by 4 to $11 \%$ during the experimental period (Fig. 1). Weight gains in the experimental group for the period of day 15 to 38 of the experiment and total weight gain from day 1 to 38 were significantly higher $(P<0.05)$ compared to the control. Group means, standard deviations, and indexes are given in Table 3.

Table 3

Live weights and weight gains $(\mathrm{kg})$ during the treatment period

\begin{tabular}{|c|c|c|c|c|c|c|c|}
\hline & & \multicolumn{2}{|c|}{ Control group } & \multicolumn{4}{|c|}{ Experimental group } \\
\hline & & $\mathrm{x}$ & $\pm \mathrm{SD}$ & Index $\%$ & $\mathrm{x}$ & $\pm \mathrm{SD}$ & Index \% \\
\hline \multirow[t]{2}{*}{ Live weight } & 17. 9 . & 8.09 & 1.08 & 100 & 8.08 & 1.02 & 99.9 \\
\hline & 1. 10 & 11.53 & 1.92 & 100 & 12 & 1.53 & 104.1 \\
\hline Weight gain & for period & 3.44 & 0.10 & & 3.92 & 1.12 & \\
\hline Live weight & 24. 10 . & 24.81 & 3.94 & 100 & 27.56 & 3.36 & 111.1 \\
\hline \multirow[t]{2}{*}{ Weight gain } & for period & 13.28 & 2.26 & & $15.56^{*}$ & 2.14 & \\
\hline & total & 16.72 & 3.03 & & $19.48 *$ & 2.80 & \\
\hline Live weight & 1.11. & 30.91 & 4.78 & 100 & 32.7 & 3.00 & 105.8 \\
\hline \multirow[t]{2}{*}{ Weight gain } & for period & 6.1 & 1.17 & & 5.14 & 1.21 & \\
\hline & total & 22.82 & 3.90 & & 24.62 & 2.61 & \\
\hline
\end{tabular}

*) $P<0.05$ significant between-group difference

Total feed consumption was $434.6 \mathrm{~kg}$ in the control group and $460.8 \mathrm{~kg}$ in the experimental group. Feed consumption per animal per day was $0.966 \mathrm{~kg}$ in the control, and 1.024 in the experimental group. Feed conversion was $1.905 \mathrm{~kg}$ in the control, and $1.872 \mathrm{~kg}$ in the experimental group. The actual feed intake in the experimental group was higher, but intake per $\mathrm{kg}$ of live weight was more favourable than in the control group. 


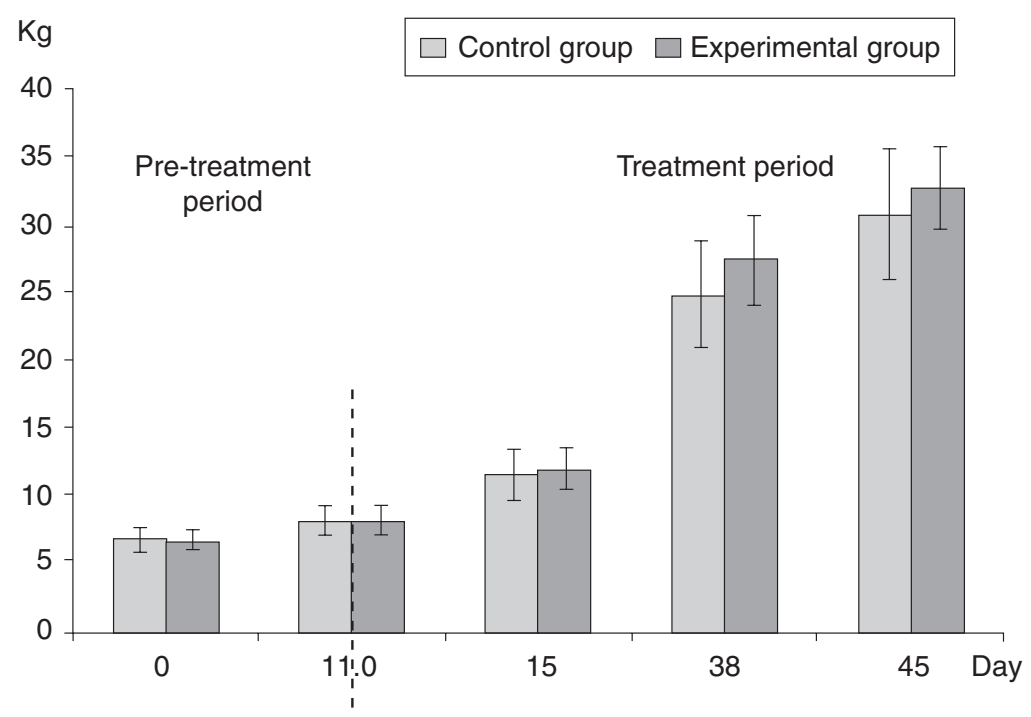

Fig. 1. Live weights $(\mathrm{kg} \pm \mathrm{SD})$ during pre-treatment and treatment periods

Age- and live weight-dependent increases in the concentrations of total protein, albumin, calcium and activity of ALT were similar in both groups. The within-group differences were significant in sporadic cases (Table 4). Low standard deviations indicate the evenness of individual values. Most of the results were within the range of physiological values published in the literature. At the beginning of the experiment, both groups showed mean ALP activities exceeding markedly the reference values but the enzyme activity decreased with advancing age. Considerable individual variations were observed in both groups. Table 4 shows individual selected biochemical characteristics.

Haematological characteristics of both control and experimental piglets were within the reference range as given by Sokol et al. (1988). Low standard deviations are indicative of small individual variations in both groups. A survey of individual values of selected haematological characteristics found in the control and experimental groups is shown in Table 5. No clinical signs of disease were observed in any of the piglets during the experimental period.

Indoor air temperature and humidity had no adverse effects on the state of health or performance characteristics. Mean indoor morning and evening air temperatures during the experimental periods were $24.1 \pm 2.4{ }^{\circ} \mathrm{C}\left(20.4\right.$ to $\left.29.4{ }^{\circ} \mathrm{C}\right)$ and $24.6 \pm 2.28{ }^{\circ} \mathrm{C}$ (20.8 to 29.5 $\left.{ }^{\circ} \mathrm{C}\right)$, respectively. Mean morning and evening air humidity during the experimental period was $51 \%$ (28 to $70 \%$ ) and $55 \%$ (39.2 to $72.3 \%$ ). Temperature and humidity conditions during the experimental period corresponded with the recommended values.

\section{Discussion}

Characteristic for the pre-treatment period was a satisfactory uniformity of live weights and growth rates. These characteristics and even the sex ratio were the decisive criteria for allotting the piglets into the control and experimental groups to ensure objective assessment of their performance and other desirable effects of Lactiferm (Enterococcus faecium M74 - NCIMB 11181).

Of characteristics that are supposed to be ameliorated after administration of microbial preparations, live weights and weight gains increased in piglets of the experimental group 
Table 4

Selected biochemical characteristics

\begin{tabular}{|c|c|c|c|c|c|}
\hline & \multirow[t]{2}{*}{ Sample } & \multicolumn{2}{|c|}{ Control group } & \multicolumn{2}{|c|}{ Experimental group } \\
\hline & & $\mathrm{x}$ & $\pm \mathrm{SD}$ & $\mathrm{x}$ & $\pm \mathrm{SD}$ \\
\hline \multirow[t]{2}{*}{$\mathrm{TP} \mathrm{g} \cdot \mathrm{l}^{-1}$} & $1^{\text {st }}$ & 55.0 & 3.7 & 55.1 & 5.14 \\
\hline & $2^{\text {nd }}$ & 66.3 & 5.14 & 64.0 & 5.3 \\
\hline \multirow[t]{2}{*}{ Alb $g \cdot l^{-1}$} & $1^{\mathrm{st}}$ & 17.6 & 4.18 & 19.0 & 3.6 \\
\hline & $2^{\text {nd }}$ & 27.2 & 5.43 & 23.0 & $3.02 *$ \\
\hline \multirow[t]{2}{*}{$\mathrm{TL} g \cdot l^{-1}$} & $1^{\text {st }}$ & 3.2 & 0.39 & 3.0 & 0.4 \\
\hline & $2^{\text {nd }}$ & 3.1 & 0.34 & 2.9 & 0.37 \\
\hline \multirow[t]{2}{*}{ Chol mmol.1 $1^{-1}$} & $1^{\text {st }}$ & 2.6 & 0.34 & 2.5 & 0.48 \\
\hline & $2^{\text {nd }}$ & 3.1 & 0.42 & 2.3 & $0.47 * *$ \\
\hline \multirow[t]{2}{*}{$\mathrm{P} \mathrm{mmol} \cdot \mathrm{l}^{-1}$} & $1^{\mathrm{st}}$ & 3.5 & 0.53 & 3.3 & 0.35 \\
\hline & $2^{\text {nd }}$ & 3.0 & 0.5 & 3.0 & 0.6 \\
\hline \multirow[t]{2}{*}{$\mathrm{Ca} \mathrm{mmol} \cdot \mathrm{l}^{-1}$} & $1^{\text {st }}$ & 2.5 & 0.15 & 2.5 & 0.18 \\
\hline & $2^{\text {nd }}$ & 2.7 & 0.13 & 2.7 & 0.24 \\
\hline \multirow[t]{2}{*}{ ALT $\mu \mathrm{kat} \cdot \cdot^{-1}$} & $1^{\text {st }}$ & 24.4 & 8.25 & 24.4 & 9.49 \\
\hline & $2^{\text {nd }}$ & 33.7 & 6.22 & 34.0 & 7.3 \\
\hline \multirow[t]{2}{*}{ AST $\mu \mathrm{kat} \cdot 1^{-1}$} & $1^{\text {st }}$ & 33.9 & 14.31 & 30.6 & 17.38 \\
\hline & $2^{\text {nd }}$ & 32.1 & 10.91 & 45.0 & 19.0 \\
\hline \multirow[t]{2}{*}{ ALP $\mu \mathrm{kat} \cdot \mathrm{l}^{-1}$} & $1^{\text {st }}$ & 813 & 224 & 867 & 194 \\
\hline & $2^{\text {nd }}$ & 544 & 74 & 518 & 126 \\
\hline \multirow[t]{2}{*}{ Gluc mmol $\cdot 1^{-1}$} & $1^{\text {st }}$ & & & & \\
\hline & $2^{\text {nd }}$ & 4.4 & 0.8 & 4.0 & 0.9 \\
\hline
\end{tabular}

$* P<0.05 \quad * * P<0.01$ significant between-group difference

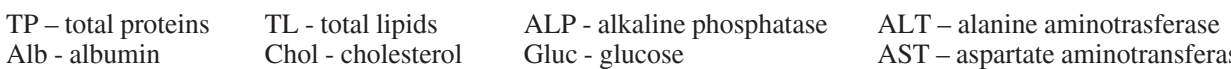

Table 5

Haematological characteristics

\begin{tabular}{llcccc}
\hline & Sample & Control group & \multicolumn{2}{c}{ Experimental group } \\
& & $\mathrm{x}$ & $\pm \mathrm{SD}$ & $\mathrm{x}$ & $\pm \mathrm{SD}$ \\
\hline $\mathrm{Er}\left[\mathrm{T} \cdot \mathrm{l}^{-1}\right]$ & $1^{\text {st }}$ & 7.39 & 0.81 & 7.00 & 1.01 \\
& $2^{\text {nd }}$ & 7.41 & 0.68 & 6.73 & 1.17 \\
$\mathrm{PCV}\left[\mathrm{I} \cdot \mathrm{l}^{-1}\right]$ & $1^{\text {st }}$ & 0.31 & 0.04 & 0.30 & 0.07 \\
& $2^{\text {nd }}$ & 0.34 & 0.03 & 0.35 & 0.04 \\
$\mathrm{Hb}\left[\mathrm{g} \cdot \mathrm{l}^{-1}\right]$ & $1^{\text {st }}$ & 144.21 & 28.47 & 147.68 & 21.50 \\
& $2^{\text {nd }}$ & $115.91^{*}$ & 15.48 & $111.8 * *$ & 23.4 \\
$\left.\mathrm{Le} \cdot \mathrm{I}^{-1}\right]$ & $1^{\text {st }}$ & 7.73 & 3.23 & 8.40 & 2.68 \\
& $2^{\text {nd }}$ & $14.29 * *$ & 2.07 & $15.4 * *$ & 3.68 \\
\hline
\end{tabular}

$* * P<0.01 \quad * P<0.05$ significant difference between $1^{\text {st }}$ and $2^{\text {nd }}$ sampling

Er-erythrocyte count

PCV - haematocrit
$\mathrm{Hb}$ - haemoglobin

Le - leukocyte count 
and feed conversion improved as shown in Table 3. The results demonstrated favourable effects of the product Lactiferm (Enterococcus faecium M74 NCIMB 11181) on gut microflora composition and its ability to eliminate microbial burden that often occurs as a result of changes in the diet. Our results monitoring the weight gains and feed consumption per $1 \mathrm{~kg}$ of weight gain confirmed earlier data published by Kumprecht et al. (1994), Gerendai and Gippert (1988), Maiolino et al. (1992) and others.

The physiological and favourable microbial population in the intestinal tract is maintained by antagonistic activity of the milk fermentation bacteria and competitive exclusion of pathogenic microorganisms. Antagonistic activity of bacteria consists in production of substances such as bacteriocins, organic acids and hydrogen peroxides (Tagg et al. 1976). Bacteriocins consist of biologically active peptides with bactericidal effect. Competitive exclusion means colonization of a certain part of an organism (digestive tract) by a population of competitive microorganisms. In fact, a more suitable population is colonizing the tract or is producing substances which are toxic for the population of undesirable microorganisms.

It was found that bacterial microflora of farm animals plays an important role in digestion and absorption of nutrients. It takes part in metabolism of nutrients and synthesis of nutrients. Supplementation with lactobacilli of rations based on maize and soya, or maize, soya and barley stimulated feed intake and increased retention of fat, nitrogen and mineral elements (Nahanshon et al. 1992; 1993; 1994; 1996).

No diseases or deaths were observed in any of the groups so that the effect of the product under study on morbidity and mortality could not be assessed. Improved welfare of the piglets was evident from the fact that no veterinary treatment was necessary and all the animals grew well up to the live weight of $32 \mathrm{~kg}$. No adverse effect of the product on selected metabolic (Tlučhoř 2001) and haematological characteristics (Sokol et al. 1988) indicative of health disorders were observed (Tables 4, 5).

The experiment was carried out under optimum hygienic conditions. It can be assumed that the microbial burden to which piglets reared on farms are exposed was absent under these experimental conditions. The results demonstrated non-significant favourable effects of the product Lactiferm (Enterococcus faecium M74-NCIMB 11181) on weight gains and feed conversion. The experimental group showed a higher live weight compared to the control, but the differences varying between 4 and $11 \%$ were nonsignificant. Weight gain in the period from day 15 to day 38 and total weight gain from day 1 to day 38 of the experiment were significantly higher $(P<0.05)$ than in the control group.

\section{Ověření růstově stimulační a protektivní účinnosti probiotika Lactiferm u selat po odstavu}

Byl doložen pozitivní vliv probiotického př́pravku Lactiferm s účinnou složkou Enterococcus faecium M 74 (NCIMB 11181) na ukazatele užitkovosti selat po odstavu. $\mathrm{V}$ celém průběhu pokusu měla pokusná skupina statisticky nevýznamně vy̌šsí hmotnost od 4,1 do $11,1 \%$. Př́irůstek hmotnosti za období mezi 15. až 38. dnem sledování a přírůstek hmotnosti celkem mezi 1. až 38. dnem pokusu byly statisticky významně vyšší než u kontroly $(P<0,05)$. Konverze krmiva byla u kontroly 1,905 a u pokusné skupiny 1,872 $\mathrm{kg}$. Hodnoty vybraných biochemických a hematologických ukazatelů se pohybovaly v rámci fyziologických, resp. referenčních hodnot. Nebyly zaznamenány klinické příznaky onemocnění selat. 


\section{References}

Anonymous: Notice No. 194/1996, Annex 3, Ministry of Agriculture CR (Vyhláška MZe ČR č. 194/1996 Sb. Př́loha č. 3)

Anonymous: Notice No. 451/2000, Annex 14, Ministry of Agriculture CR (Vyhláška MZe č. 451/2000 Sb. Př́íloha č. 14)

Anonymous: Notice No. 451/2000, Annex 20, Ministry of Agriculture CR (Vyhláška MZe č. 451/2000 Sb. Př́iloha č. 20)

Anonymous: Commission directive of 22. July 1994 amending Council Directive 87/153/EEC fixing guidelines for the assessment of additives in animal nutrition (94/40/EC)

FULLER, R 1989: Probiotics in man and animals. A review. J Appl Bacteriol 66: 365-378

FULLER, R 1992: Probiotics. The Scientific Basis. London, Chapman and Hall. 398 p.

GEDEK, BR 1990: Zum Wirkungsmechanismus von Probiotika. In: Proc. Int. Symp. Probiotics in the Nutrition of Animals, Dům techniky Brno: 1-16

GERENDAI, D,GIPPERT, T 1988: Effect of the application of Streptococcus faecium M - 74 on the production results of broiler chickens. Proceedings of XVIII Worlds Poultry Congress, September 4-9, Nagoya, Japan: $850-851$

GHADBAN, GS 2002: Probiotics in broiler production - a review. Arch Geflügelk 66: 49-58

GOLDIN, BR, GORBACH, SL 1984: Alterations of the intestinal micro-flora by diet, oral antibiotic and Lactobacillus: Decreased production of free amines from aromatic nitro compounds, azo dyes and glucuronides. J Natl Cancer Inst 73: 689-695

HERICH, R, LEVKUD, M 2002: Lactic acid bacteria, probiotics and immune system. Vet Med - Czech 47: $169-180$

KUMPRECHT, I, ZOBAČ, P, SVOZIL, B 1990: Mikrobiotikum und enzymatische Präparate in der Ernährung von landwirtschaftlichen Nutztieren. In: Proc. Int. Symp. Probiotics in the Nutrition of Animals, Dủm techniky Brno: 27-50

KUMPRECHT, I, ZOBAČ, P 1998a: The effect of probiotic preparations containing Saccharomyces cerevisce and Enterococcus faecium in diets with different levels of B-vitamins on chicken broiler performance. Czech J Anim Sci 43: 63-70

KUMPRECHT, I, ZOBAČ, P 1998b: Study of the effect of a combined preparation containing Enterococcus faecium M-74 and mannan-oligosaccharides in diets for weanling piglets. Czech J Anim Sci 43: 477-481

KUMPRECHT, I, ZOBAČ, P, ROBOŠOVÁ, E 1994:The effect of Bacillus C. I. P. 5832 applications on some physiological parameters and performance of weanling piglets. Živoč Výr 39: 331-342

MATOUŠKOVÂ, O, CHALUPA, J, CÍGLER, M, HRUŠKA, K 1992: Stat plus. VÚVeL Brno. 168 p.

MAIOLINO, R, FIORETTI, A, MENNA, LF, MEO, C 1992: Research on the efficiency of probiotics in diets for broiler chickens. Nutrition Abstract and Reviews, Series B, 62: 482

MICHARD, J, LEVESQUE, A 1989: Stabilité du Paciflor (Bacillus C.I.P. 5832) dans les présentations commerciales et les aliments. Méthodes de dénombrement. Bull Inf Station Exp. dęAviculture de Ploufragan 29: $146-15$

NAHANSHON, SN, NAKAUE, HS, MIROSH, LW 1992: Effect of direct-fed microbials on nutrient retention and parameters of laying pullets. Poultry Sci 71, Suppl. 1: 111

NAHANSHON, SN, NAKAUE, HS, MIROSH, LW 1993: Effect of direct-fed microbials on nutrient retention and parameters of Single Comb White Leghorn pullets. Poultry Sci 72, Suppl.2: 87

NAHANSHON, SN, NAKAUE, HS, MIROSH, LW 1994: Performance of Single Comb White Leghorn laying pullets fed diets supplemented with direct-fed microbials. Poultry Sci 73: 1699-1711

NAHANSHON, SN, NAKAUE, HS, MIROSH, LW. 1996: Performance of Single Comb White Leghorn layers fed with a live microbial during the growth and egg laying phases. Animal Sci and Technol 57: 25-38

NGUYEN, TH 1989: Paciflor: un nouveau biorégulateur. Aliscope, 8-9: 14-16

NGUYEN, TH, ECKENFELDER, B, LEVESQUE, A 1988: Growth promoting efficiency of two probiotics, Toyocerin and Paciflor, in broiler diets. Arch Geflügelk 52: 240-245

SOKOL, J, GAJDOŠÍK, D, DUŠEK, J, OFÚKANY, J 1988: Referenčné hodnoty vybraných ukazatelov metabolickej testácie hospodárskych zvierat a postup pri ich využívaní v diagnostike. ÚVIO Bratislava. 43 p.

ŠIMEČEK, K, ZEMAN, L, HEGER, J 1993: Potřeba živin a tabulky výživné hodnoty krmiv pro prasata. ČAZV, Pohořelice. $78 \mathrm{p}$.

TAGG, J.R., DAJANI, A.S., WANNAMAKER, L.W. 1976: Bacteriocins of gram-positive bacteria. Bact Reviews 40: $722-756$

TLUČHOŘ, V 2001: Hodnocení biochemických výsledků ve veterinární medicíně z pohledu jedince a stáda. Krmivářství 5, 2: 18-20 